\title{
EVALUATION OF CRYOPROBE BIOPSY IN DIAGNOSIS OF ENDOBRONCHIAL TUMORS
}

\author{
By \\ Magdy Shouhdy Taha Ibrahim, Ahmed Ali Abu-Naglah, Ahmed \\ Mohamed Ali Ewis, Al-Sayed Mohamed Ibrahim Tealeb* \\ Department of Chest Diseases and Pathology*, Faculty of Medicine, Al-Azhar University \\ Corresponding author: Magdy Shouhdy Taha Ibrahim, \\ Mobile: 01003706480; E-mail: noshamagdy48@gmail.com
}

\begin{abstract}
Background: The cryoprobe is a closed system that can be re-sterilized and reused. It is well established as a safe procedure in taking endobronchial biopsies. Recent reports have risen as an alternative of the traditional forceps methods.

Objective: To assess the diagnostic yield and safety of cryoprobe in patients with endobronchial neoplasms.

Patients and Methods: Thirty patients who underwent bronchoscopy were included in this study at Chest diseases Departments (Endoscopic Unit) of Al -Azhar University Hospitals from August 2018 to August 2020 hospital. Endobronchial biopsies were taken by forceps biopsy and cryobiopsy with ERBE cryo probe from each subject.
\end{abstract}

Results: Twenty-five patients (83.33\%) were diagnosed using cryoprobe biopsy, while 18 patients $(60 \%)$ were diagnosed with forceps biopsy $(\mathrm{P}<0.05)$. Bleeding was the recorded complication in both procedures with no significant difference between them in the incidence of bleeding.

Conclusion: Cryoprobe biopsies were more successful than forceps biopsies in the diagnosis of lung cancer.

Key words: Cryoprobe Biopsies, Forceps Biopsies, Bronchoscopy, Endobronchial Tumor.

\section{INTRODUCTION}

Bronchoscopy is still the mainstay of approaching endobronchial lesion. The conventional methods to obtain specimen include forceps biopsy, brushing or washing the lesion under direct vision. However, the diagnostic yield of conventional forceps biopsy is limited because of the small size of tissue sample and crush artifacts (Hetzel et al., 2011).

Cryobiopsy as a tool in bronchology has been introduced on a routine basis in recent years and has been found to be safe in routine diagnostic setting (Schumann et al., 2010).
Introduction of a new sampling technique is another opportunity to increase the diagnostic yield. The flexible cryoprobe is primarily used for cryoextraction of malignant airway stenosis and was introduced as an alternative method for mechanical tumor debulking, which is immediately effective (Schumann et al., 2010). Because of extraordinarily well-preserved tissue samples (larger in size with less mechanical damage and mostly vital tumor) from cryocanalization procedures, the technique has been transferred to the biopsy of endobronchial lesions. The 
determination of histopathological cell type and stage of primary lung carcinoma is crucial to develop appropriate treatment approach that affects morbidity and mortality (Rivera et al., 2013).

Newly developed cryotechnology provide larger sample than that of conventional forceps biopsy and have better diagnostic yield (Hetzel et al., 2012).

The present study aimed at assessing the diagnostic yield and safety of cryoprobe in patients with endobronchial neoplasms.

\section{PATIENTS AND METHODS}

This study was done at Chest diseases Departments in the endoscopic unit of $\mathrm{Al}$ Azhar University Hospitals from August 2018 to August 2020

This prospective study was for evaluation of efficacy as determined by the diagnostic yield and safety of cryobiopsy in comparison to endobronchial forceps biopsy. Thirty patients (22 males and 8 females) with suspected endobronchial neoplasm (clinically and radiologically) were included in this study.

Inclusion criteria: Patients with endobronchial tumor (endoscopically visible lesion) based on clinical and radiological data (chest X-ray and computed tomography), adult (age above
18 years or more) and signed informed consent and sufficient respiratory function (oxygen saturation > $90 \%$ without oxygen).

Exclusion criteria: Severe uncorrected hypoxemia despite the administration of supplemental oxygen, unstable cardiovascular or hemodynamic status, coagulation defects, the prothrombin concentration less than $70 \%$, suspected connection of the lesion to large pulmonary blood vessels as seen on chest computed tomography scan and age less than 18 years.

Bronchoscope was indicated in patients who came with dyspnea and radiological chest mass suggested endobronchial tumor.

\section{Statistical Analysis of data:}

Data were analyzed using Statistical Package for the Social Sciences (SPSS) version 15.0. Quantitative data were expressed as mean \pm standard deviation (SD), while qualitative data were expressed as frequency and percentage.

Chi-square was used when comparing two means.

P-value $\leq \mathbf{0 . 0 5}$ was considered significant. 


\section{RESULTS}

This was a statistically significant difference (p-value $<0.05)$ between cryoprobe and forceps biopsies as regard diagnosis (Table 1).

Table (1): Comparison between cryoprobe and forceps biopsy as regard diagnosis in studied patients

\begin{tabular}{|c|c|c|c|c|c|}
\hline $\begin{array}{ll}\text { Diagnosis of malignancy } & \text { Biopsy } \\
\end{array}$ & \multicolumn{2}{|c|}{$\begin{array}{c}\text { Cryoprobe } \\
(\mathrm{N}=30)\end{array}$} & \multicolumn{2}{|c|}{$\begin{array}{l}\text { Forceps } \\
(\mathrm{N}=30)\end{array}$} & p-value \\
\hline Diagnostic & 25 & $83.3 \%$ & 18 & $60 \%$ & \multirow{2}{*}{0.045} \\
\hline Non & 5 & $16.7 \%$ & 12 & $40 \%$ & \\
\hline
\end{tabular}

$\mathrm{X} 2$ : Chi-square test;

This was no statistically significant difference (p-value > 0.05) between cryoprobe and forceps biopsies as regard post procedure complications. Post forceps complications in studied patients were bleeding (mild) in $10 \%$, pneumothorax in $10 \%$ while there were no complications in $80 \%$. Post cryoprobe complications were bleeding (mild) in $13.3 \%$ while there were no complications in $86.7 \%$ (Table 2).

Table (2): Comparison between cryoprobe and forceps biopsy as regard complications in studied patients

\begin{tabular}{|c|c|c|c|c|c|}
\hline Complications Biopsy & \multicolumn{2}{|c|}{$\begin{array}{c}\text { Cryoprobe } \\
(\mathrm{N}=30)\end{array}$} & \multicolumn{2}{|c|}{$\begin{array}{l}\text { Forceps } \\
(\mathrm{N}=30)\end{array}$} & p-value \\
\hline No & 26 & $86.7 \%$ & 24 & $80 \%$ & \multirow{2}{*}{0.488} \\
\hline Yes & 4 & $13.3 \%$ & 6 & $20 \%$ & \\
\hline
\end{tabular}

$\mathrm{X} 2$ : Chi-square test;

Cry biopsy is a safe technique with a diagnostic yield, which is comparable to that of conventional forceps biopsy (Table 3).

Table (3): Comparison between cryoprobe and forceps biopsy as regard complications and diagnosis in studied patients

\begin{tabular}{|c|c|c|c|c|c|c|}
\hline \multirow{2}{*}{ parameters } & Biopsy & \multicolumn{2}{c|}{$\begin{array}{c}\text { Cryoprobe } \\
(\mathrm{N}=30)\end{array}$} & \multicolumn{2}{c|}{$\begin{array}{c}\text { Forceps } \\
(\mathrm{N}=30)\end{array}$} & \multirow{2}{*}{ p-value } \\
\hline \multirow{2}{*}{ Diagnosis } & Diagnostic & 25 & $83.3 \%$ & 18 & $60 \%$ & \multirow{2}{*}{0.045} \\
\cline { 2 - 7 } & Non & 5 & $16.7 \%$ & 12 & $40 \%$ & \multirow{2}{*}{0.488} \\
\hline \multirow{2}{*}{ Complications } & No & 26 & $86.7 \%$ & 24 & $80 \%$ & \multirow{2}{*}{ Yes } \\
\cline { 2 - 6 } & 4 & $13.3 \%$ & 6 & $20 \%$ & \\
\hline
\end{tabular}

\section{DISCUSSION}

The main age of studied patients was $56.6 \pm 13.01$ which came in agreement with El-Dahdouh et al. (2015) who performed three bronchoscopic forceps biopsies and one cryobiopsy for each patient.
As regard gender, $73.3 \%$ of patients were males and $26.7 \%$ females, as males are more liable to lung cancer than females which came in agreement with Jabari et al. (2012) who reported a male 
predominance among his studied 40 patients.

Among the study population, $36.7 \%$ of patients were nonsmokers, and $63.3 \%$ of patients were smokers, as smokers are more liable to lung cancer than nonsmokers which came in parallel with El-Dahdouh et al. (2015).

The lesion was right -sided in $53.3 \%$ of patients, while $46.7 \%$ of them had leftsided lesions with no statistically significant difference between both sides. This was correlated with Schumann et al. (2010) who compare between cryoprobe and forceps biopsy in diagnosis of endobronchial lung cancer.

In this study, for cryoprobe biopsy, one biopsy was taken in $73.3 \%$ and two biopsies were taken in $26.7 \%$. For forceps biopsy, three biopsies were taken in $56.7 \%$, and four biopsies were taken in $43.3 \%$.

These results indicated that numbers of biopsies taken by cryoprobe were smaller in number and larger in size than those taken by forceps, which helped in increasing the yield of diagnosis by cryoprobe. This observation was matched with Schumann et al. (2010). Our results were convenient with Hetzel et al. (2012) who studied patients with final diagnosis of cancer. Also, our results came in agreement with El-Dahdouh et al. (2015) as regard the number of biopsies in each studied group.

As regard histopathological diagnosis by cryoprobe biopsy in studied patients, adenocarcinoma was revealed in $16.7 \%$, adenocarcinoma (mucus- secreting variant) in $6.7 \%$, atypical carcinoid in $13.3 \%$, dense lymphocytic infiltrate in
$3.3 \%$, inflammatory process in $6.7 \%$, inflammatory reaction with squamous metaplasia in $3.3 \%$, moderate focal dysplasia in $3.3 \%$, necrotic tissue in $3.3 \%$, non-small cell lung carcinoma in 3.3\%, small cell lung carcinoma in $10 \%$, small round cell tumor in $3.3 \%$ and squamous cell carcinoma in $26.7 \%$.

In the current study, the diagnosis was achieved in $83.3 \%$ of cryoprobe biopsies. This was compatible with Schumann et al. (2010) who achieved diagnosis in $89.1 \%$ of cases of cryoprobe biopsy. On the other hand, our study opposed that of $\mathrm{El}$ Dahdouh et al. (2015) who achieved diagnosis in $100 \%$ of total cases of cryoprobe biopsy.

As regard histopathological diagnosis by forceps biopsy in studied patients, adenocarcinoma was revealed in $10 \%$, adenocarcinoma (mucus- secreting variant) in $6.7 \%$, atypical carcinoid in $6.7 \%$, dense lymphocytic infiltrate in $3.3 \%$, inflammatory process in $23.3 \%$, inflammatory reaction with squamous metaplasia in $3.3 \%$, necrotic tissue in $10 \%$, non-small cell lung carcinoma in $3.3 \%$, small cell lung carcinoma in $10 \%$, small round cell tumor in $3.3 \%$ and squamous cell carcinoma in $20 \%$.

The above results showed that the diagnosis was achieved in $60 \%$ of total cases of forceps biopsy. This was incompatible with Schumann et al. (2010) who achieved diagnosis in $65.5 \%$ of forceps biopsy. On the other hand, our study results mismatched with $\mathrm{El}$ Dahdouh et al. (2015) who achieved diagnosis in $80 \%$ of cases of forceps biopsy.

As regard diagnosis, there was a statistically significant difference between 
cryoprobe and forceps biopsies. The cryoprobe was diagnostic in $83.3 \%$ of patients and non-diagnostic in $16.7 \%$ of them, while forceps biopsy was diagnostic $60 \%$ of patients and non-diagnostic in $40 \%$ in the remainders. These corresponded with Schumann et al. (2010) who and revealed a significantly higher diagnostic yield for cryobiopsy compared with forceps biopsy. Also, this study was parallel to Hetzel et al. (2012) who achieved definitive diagnosis in $85.1 \%$ of patients by forceps biopsy, and $95.0 \%$ of patients who underwent cryobiopsy, irrespective his higher percentage of diagnosis by cryoprobe and forceps biopsy because of his large sample comparing to ours.

Our results disagreed with Rubio et al. (2013) who studied patients with endobronchial lung lesion underwent cryoprobe and forceps biopsies and achieved definitive diagnosis in $96.77 \%$ of patients by cryoprobe biopsy, and $95.45 \%$ by forceps biopsy without a statistically significant difference ( $p$-value $>0.05$ ).

As regard complications, there were no statistically significant differences between cryoprobe and forceps biopsy. The only post cryoprobe biopsy complication was bleeding which occurred in $13.3 \%$ while $86.7 \%$ showed no complications. On the other hand, post forceps biopsy complications were bleeding occurred in $10 \%$, and pneumothorax in $10 \%$ with no recorded complications in $80 \%$. These were balanced with Schumann et al. (2010) who reported that there was no statically significant difference between complications between cryoprobe and forceps biopsy.
As regard post cryoprobe bleeding, Schumann et al. (2010) reported bleeding in about $27 \%$ of cases. These were regarded as mild bleeding in $20 \%$ cases, moderate bleeding in $5 \%$, and severe bleeding in only one case, while in this study post cryoprobe bleeding complications were in $13 \%$. Also, this study agreed with El-Dahdouh et al. (2015) who reported that hemorrhage was the only complication in both procedures, with no significant difference between these two procedures in the incidence of hemorrhage. Hetzel et al. (2012) results were convenient with this study. They reported a close rate of severe bleeding of $17.8 \%$ and $18.2 \%$ for forceps and cryoprobe. Rubio et al. (2013) reported one minor bleeding of total 22 cases underwent cryoprobe biopsy of endobronchial lung lesion. Oormila et al. (2016) reported that the bleeding incidence in $\mathrm{CB} / \mathrm{CTBB}$ was $23.76 \%$, and that of FB/FTBB was $20.83 \%$ with no significant difference in bleeding severity.

\section{CONCLUSION}

Cryoprobe biopsy is a safe and feasible method for endobronchial lesions with a comparable bleeding rate to that of forceps biopsy. Cryoprobe has a significantly higher diagnostic yield than forceps biopsy.

\section{REFERENCES}

1. El-Dahdouh S, Abd Elaal GA and El-kady N (2015): Comparison between endobronchial forceps-biopsy and cryobiopsy by flexible bronchoscopy. Egyptian Society of Chest Diseases and Tuberculosis, 65: 325-329.

2. Hetzel J, Eberhardt R, Herth FJ, Petermann C, Reichle G, Freitag L, Dobbertin I, Franke KJ, Stanzel F and Beyer T (2012): Cryobiopsy increases the 
diagnostic yield of endobronchial biopsy: a multi centretrial. Eur Respir J, 39:685-690.

3. Hetzel J, Hetzel M and Hasel C (2011): Old meets modern: the use of traditional cryoprobes in the age of molecular biology. Respiration, 76:193-7.

4. Jabari H, Sami R, Fakhri M and Kiani A (2012): Different protocols for cryobiopsy versus forceps biopsy in diagnosis of patients with endobronchial tumors, Pneumologia, 61 (4): 230-233.

5. Oormila G, Shu LG, Manu C and Yi SL (2016): Efficacy and safety of cryobiopsy versus forceps biopsy for interstitial lung diseases and lung tumours: A systematic review and meta-analysis Respirology, 21: 834-841.
6. Rivera MP, Detterbeck F, Mehta AC (2013): Diagnosis of lung cancer: The guidelines. Chest, 123:129-36.

7. Rubio ER, Whatley RE and Boyd MB (2013): Cryobiopsy: should this be used in place of endobronchial forceps biopsies? BioMed research international. Respirology, 16:552-557.

8. Schumann C, Hetzel J, Babiak AJ, Merk T, Wibmer T, Möler P, LepperPM and Hetzel M (2010): Cryoprobe biopsy increases the diagnostic yield in endobronchial tumor lesions. J Thorac Cardiovasc Surg, 140:417-421. 


\section{تقييم دور الخزعة بواسطة مسبار التبريد في تشخيص اورام الثعب الهو ائية}

مجدى شهذى طه (براهيم، أحمد على أبونجلة، أحمد محمد على عويس، السيد محمد

$$
\text { (ابراهيم تعليب }
$$

قسمى الأمر اض الصدرية والباثولوجى*، كلية الطب، جامعة الازهر

E-mail: noshamagdy48@gmail.com

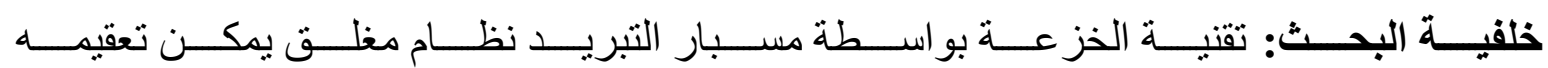

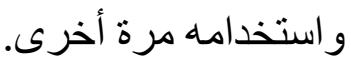

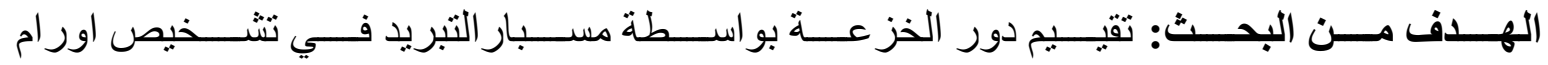
الشعب الهو ائية.

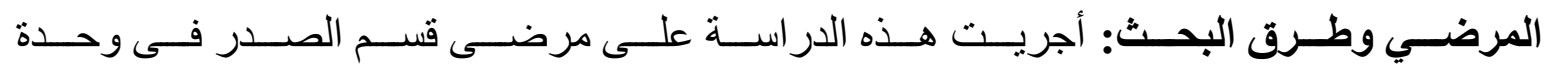

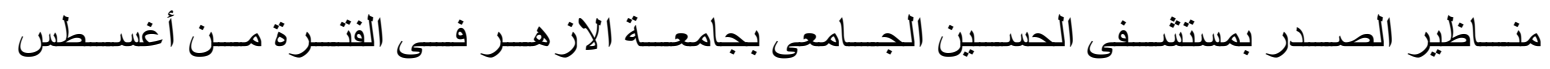

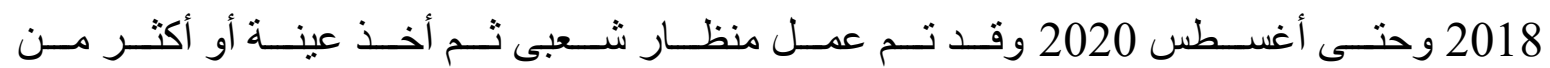
أورام الثُعب الهو ائية عن طريق الملقط الليفى ومسبار التبريد من نفس المريض.

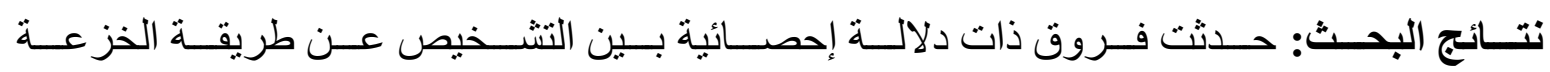

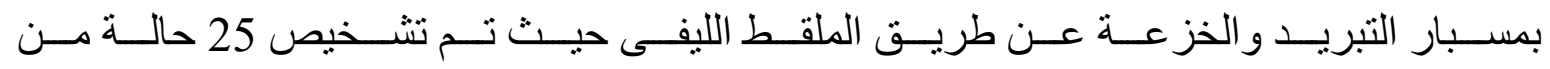

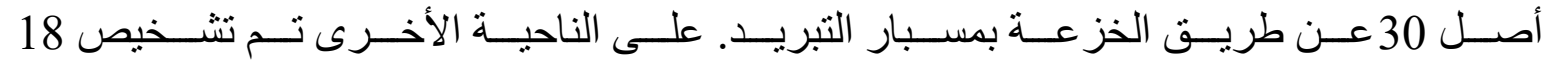

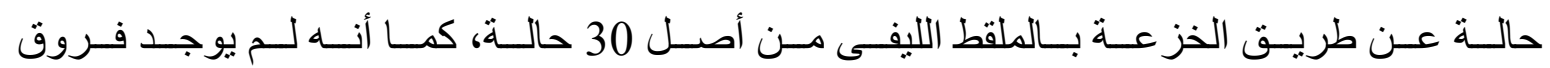

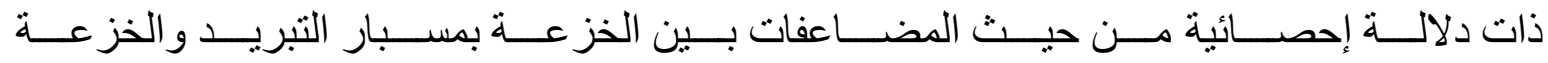
بالملقط الليفى.

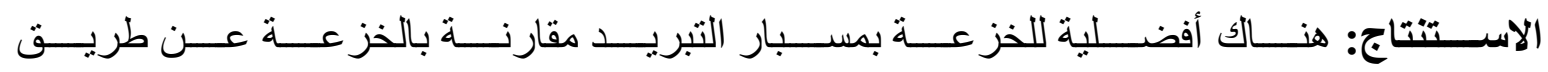
الملقط الليفى من حيث التشخيص ووسائل الأمان.

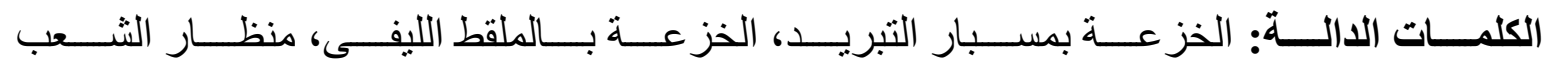
الهو ائية، أورام الثعب الهو ائية. 